\title{
Liberalismo a prueba. La expulsión de «extranjeros perniciosos» en México durante la República Restaurada (1867-1876)
}

\author{
por \\ Paola Chenillo Alazraki \\ Universidad Nacional Autónoma de México
}

En México, durante la República Restaurada (1867-1876), a pesar de que el liberalismo se afianzó como un elemento fundamental en la vida política nacional, la defensa de la igualdad jurídica quedó supeditada al fortalecimiento del Estado y del partido en el poder. En este artículo, se analiza la expulsión de 17 jesuitas de origen extranjero, decretada en 1873 por el presidente Sebastián Lerdo de Tejada. El seguimiento detallado de los acontecimientos y del debate que generó pone en evidencia el papel de esta facultad como una herramienta política en dicho proceso.

Palabras clave: liberalismo; República Restaurada; Compañía de Jesús; extranjeros.

En México, el triunfo de la revolución de Ayutla en el verano de 1855 abrió las puertas a una generación de políticos comprometidos con el ideario liberal. Estos hombres - entre los que destacan Ignacio Ramírez, Francisco Zarco, Manuel Altamirano, Ignacio Vallarta y Benito Juárez- buscaban crear una sociedad conformada por individuos libres e iguales ante la ley que se comportaran de acuerdo a los cánones de la modernidad y confiaban en que la promulgación de una Carta Magna, que garantizara los derechos de los ciudadanos y pusiera límites a la autoridad del gobierno, sería el primer paso para alcanzar la meta delineada ${ }^{1}$.

A principios del siguiente año, tal como estaba previsto en el plan con el que se levantaron en armas, iniciaron las sesiones del Congreso Constituyente $\mathrm{y}$, tras varios meses de debates, la nueva ley fundamental se promulgó el

1 Hale, 1995; 2000; 2002. 
5 de febrero de 1857. En términos políticos, estableció una república federal y dotó al poder Legislativo de mayor autoridad que a los dos restantes. De forma novedosa, se dio derecho de votar y ser votado a todos los ciudadanos sin importar su renta, y, además de incluir un capítulo referente a las garantías individuales, en el primer artículo se determinó que estas serían «la base y el objeto de las instituciones sociales» ${ }^{2}$. Concluidas las labores, Francisco Zarco admitió que los resultados estaban muy lejos de lo que inicialmente habían esperado. Aseveró que se habían declarado los «más bellos principios» y proclamado «grandes verdades sociales», pero que a cada principio se le había puesto una restricción y cada verdad había sido admitida con reservas ${ }^{3}$.

Sin duda, uno de los puntos en los que la Carta Magna fallaba frente al ideario liberal era el artículo 33, en el que se puntualizaba que los extranjeros gozarían de todas las garantías reconocidas en esta, al tiempo que dotaba al gobierno de facultades para «expeler a los perniciosos» sin precisar quiénes eran estos ni el procedimiento para hacerlo. Por lo que puede inferirse de la crónica parlamentaria, existía cierto consenso en torno a la necesidad de incluir semejante potestad, pero los legisladores eran conscientes de que esta violentaba el espíritu de la Constitución. En el borrador inicial, no estaba contemplada, pero, cuando llegó el turno en el debate al artículo relativo a los extranjeros, el diputado Eulogio Barrera advirtió que no era conveniente negarle al gobierno dicha prerrogativa. De inmediato, Ponciano Arriaga, confesando que quizás era «menos liberal» que los demás, secundó la moción. Al parecer, la única voz que se alzó en contra fue la de Francisco J. Villalobos quien enérgicamente señaló que o se concedían los derechos del hombre a los extranjeros o se declaraba que los extranjeros no eran hombres ${ }^{4}$.

A lo largo de los siguientes años, el artículo 33 seguiría causando controversia. En determinadas coyunturas, se alzaron voces exigiendo su revocación o, al menos, su reglamentación. En 1861, el diputado José María Mata im-

2 En las Bases Orgánicas de 1843, ya se estipulaban algunos derechos para todos los habitantes de la República, como la libertad de expresión y de imprenta (salvo en escritos vinculados al dogma religioso y a la vida privada), la inviolabilidad de la propiedad y el derecho al debido proceso. Pero, en la Constitución Federal de 1857, estos se hicieron más amplios. Se reconoció la libertad de enseñanza, de profesión, de trabajo, de asociación y de tránsito. Además, se desecharon los títulos nobiliarios y los fueros especiales $\mathrm{y}$, si bien no se decretó de manera explícita la libertad de cultos, ya no se instituyó la religión católica como la única tolerada.

3 Zarco, 2003: 346-348.

4 Para las discusiones suscitadas en torno al artículo 33 de la Constitución de 1857 (artículo 38 en el proyecto inicial), véase el debate de las sesiones del 27 y 29 de agosto de 1856 , en Zarco, 1857, tomo 2: 235-244. 
pulsó un proyecto de reforma constitucional con el objeto de armonizar la ley fundamental con los principios liberales que, entre otras cuestiones, contemplaba eliminar la facultad de expulsión ${ }^{5}$. Si bien la iniciativa no prosperó, dio pie a un intercambio, a través de las páginas de El Siglo Diez y Nueve, entre este legislador y Francisco Zarco, que da cuenta de las dos posturas que estaban en juego. Para Mata, lo primordial era la defensa de los derechos del hombre - y no solo los del ciudadano - por lo que no era admisible el establecimiento de diferencias entre nacionales y extranjeros. En cambio, con una visión más pragmática, Zarco consideraba que la prioridad era salvar a la República de los «gravísimos males» — reales o potenciales- que la aquejaban. Admitía que, para evitar casos de «injusta arbitrariedad», era conveniente limitar de algún modo el poder del Ejecutivo y proponía que las expulsiones fuesen ordenadas por acuerdo unánime del consejo de ministros ${ }^{6}$.

Quince años después, Pablo Macedo y Emilio Prado publicaron un Compendio de los derechos y obligaciones del hombre y del ciudadano. Estos abogados, quienes en las décadas por venir llegarían a desempeñar un papel importante en el terreno de la jurisprudencia en México, reconocían la conveniencia de conceder al presidente la facultad de expulsar a los extranjeros perniciosos, pero enfatizaban que era necesario limitarla con ciertos procedimientos que permitieran al afectado presentar pruebas a su favor?

A pesar de los intentos de reforma y de las opiniones favorables a su regulación, dicho precepto no sufrió cambio alguno mientras estuvo en vigor la

5 «Reformas constitucionales», El Siglo Diez y Nueve (México, 27 de marzo de 1861): 3; «Sesión del 13 de mayo de 1861 del Soberano Congreso», El Siglo Diez y Nueve (México, 14 de mayo de 1861): 1.

Por las mismas fechas, otros legisladores hicieron una propuesta para modificar el artículo 33 que tampoco tuvo éxito. «Sesión del 28 de mayo de 1861 del Soberano Congreso», El Siglo Diez y Nueve (México, 29 de mayo de 1861): 1.

6 Zarco, Francisco, «Reformas constitucionales», El Siglo Diez y Nueve (México, 19 de octubre de 1861):1 y (México, 24 de octubre de 1861): 1. Mata, José María, «Reformas constitucionales», El Siglo Diez y Nueve (México, 5 de noviembre de 1861): 1, y (México, 1 y 8 de noviembre de 1861): 1.

7 Macedo y Pardo, 1875: 147-150. En esta línea, también vale hacer referencia a los Apuntamientos para el estudio del derecho constitucional mexicano de José María del Castillo Velasco, ministro de la Suprema Corte de Justicia. En este libro, publicado en 1871, el autor señalaba que la primera parte del artículo 33, en la que se reconocía que los extranjeros tenían derecho a las garantías otorgadas por la constitución, era una muestra de «franca hospitalidad», pero que si algún extranjero resultaba pernicioso para la República ya fuera por su intervención en cuestiones políticas, por fomentar el desorden o por dedicarse a actividades inmorales e ilegales, el gobierno, siguiendo principios «universalmente» reconocidos, tenía el derecho de expelerlo (Castillo Velasco, 1871: 85). 
Constitución de 1857. ¿Cómo explicar su aprobación y permanencia en un contexto en el que la igualdad de los hombres ante la ley y el respeto de las garantías individuales se habían convertido en una de las principales banderas del grupo en el poder? ¿En qué condiciones estaban dispuestos a quebrantar sus convicciones? ¿Cómo lo justificaban?

En México, la potestad de expulsar extranjeros estaba lejos de ser una novedad. En 1824 y 1832, se aprobó como una medida extraordinaria de seguridad y, seis años más tarde, se elevó a rango constitucional. Inicialmente la decisión estuvo determinada por el complejo contexto internacional al que el país tuvo que hacer frente tras la consumación de la Independencia. La negativa de las Cortes españolas a reconocer la emancipación y el apoyo brindado por la Santa Alianza a Fernando VII para restaurar el absolutismo, alimentaron el temor de un posible intento de reconquista. Los debates legislativos y las expulsiones registradas dan cuenta de la desconfianza ante la presencia de espías que pudiesen poner en riesgo la soberanía nacional o escritores que entorpeciesen las relaciones con las principales potencias extranjeras ${ }^{8}$.

En las siguientes décadas, si bien los conflictos internacionales seguirían alimentando el recelo general frente a los extranjeros, la ratificación de esta medida tuvo más que ver con el papel que estos jugaron en las disputas internas. Como lo muestran los casos concretos, la expulsión se convirtió en una herramienta de control político que servía para deshacerse o intentar controlar a periodistas u hombres de negocios que apoyaban al bando enemigo durante los procesos electorales, como Rafael de Rafael, director del diario conservador El Universal, quien se mostró contrario a la candidatura de Mariano Arista en las elecciones de 1850, lo mismo que para intentar controlar a hombres de negocios como José Welsh quien, al igual que otros comerciantes del puerto de Veracruz, apoyó el levantamiento encabezado por Juan Climaco Rebolledo en diciembre del siguiente año9. Así, la expulsión, además de una evidencia del complejo papel que desempeñaron los extranjeros residentes en México y sus respectivas representaciones diplomáticas, puede entenderse como una muestra de la debilidad del Estado mexicano y, en consecuencia, de las dificultades para resolver los problemas por otras vías.

En este artículo, nos centraremos en uno de los episodios más emblemáticos: la expulsión decretada en 1873 por Sebastián Lerdo de Tejada en contra de 17 jesuitas que, contraviniendo las Leyes de Reforma, continuaban

\footnotetext{
8 Para un estudio de la legislación, de los debates en torno a esta facultad y de los casos concretos de expulsión, véase Chenillo, 2009.

9 Chenillo, 2009: 60-71.
} 
viviendo en comunidad. El seguimiento detallado de los acontecimientos y del debate que se generó en los círculos políticos y la opinión pública de la época pone en evidencia el papel de dicha facultad como herramienta política en el complejo contexto de la consolidación del Estado-nación.

Si bien la restauración de la República en 1867 abrió las puertas para el afianzamiento del liberalismo como un elemento fundamental de la vida política nacional, hay consenso en torno a que, durante dicho periodo, existió cierta distancia entre el ideario y las prácticas concretas. Con el afán de fortalecer al Estado, los presidentes Benito Juárez y Sebastián Lerdo de Tejada optaron por dotar al Ejecutivo de mayor poder que al Legislativo, por someter los gobiernos locales al federal y por sacrificar los derechos y las libertades individuales en aras de garantizar la seguridad de la nación ${ }^{10}$. En este contexto, el artículo 33 constitucional alcanzó un importante grado de consenso en las esferas políticas del país.

\section{REFORMA EN MARCHA, LIBERTADES EN SUSPENSO}

Tras la derrota a las fuerzas imperiales en el verano de 1867, el gobierno republicano tuvo que hacer frente a importantes retos, como el restablecimiento del orden legal, la reconciliación con el bando enemigo y la mediación al interior del propio partido liberal. Tomando en cuenta las condiciones del país, Benito Juárez consideró que era más prudente adoptar una política de conciliación con la Iglesia Católica que una de enfrentamiento. Su sucesor, en cambio, asumió una postura más beligerante.

En julio de 1872, tan solo unos días después de ocupar el cargo, Sebastián Lerdo de Tejada anunció que su gobierno pondría especial énfasis en el respeto a la Constitución y a las Leyes de Reforma. En términos generales, ello implicaba echar a andar el registro civil, evitar la existencia clandestina de órdenes monásticas, asegurarse de que no se efectuaran manifestaciones de devoción fuera de los templos y que los ministros de culto solo vistieran como tales en los recintos correspondientes ${ }^{11}$. De acuerdo con los estudiosos del periodo, semejante actitud debe entenderse como una estrategia política para

10 Aguilar Rivera, 2001. Ávila, 2007. Brading, 20/1 (Cambridge, mayo de 1988). Cosío Villegas, 1973. Hale, 2002, XLVI/4 (México D.F., abril-junio de 1997). Hamnett, 76/4 (Durham, noviembre de 1996). Perry, XXIII/4 (México D.F., abril-junio de 1974).

11 En un manifiesto difundido el 27 de julio de 1872, después de lamentar la repentina muerte de Juárez, aseveró que la legalidad sería la guía de su gobierno y específicamente se refirió al deber por velar por «la fiel observancia de las leyes de reforma, que han afirmado y perfeccionado nuestras instituciones». «Comunicado de Sebastián Lerdo de Tejada, presi- 
allegarse a los sectores liberales más radicales. La posición del nuevo presidente era especialmente complicada porque, dados los antecedentes familiares y su propia trayectoria académica y profesional, durante la campaña electoral lo habían acusado de ser el candidato del clero. Se le achacaba, por ejemplo, que uno de sus tíos había sido un miembro destacado de la Compañía de Jesús y, todavía más grave, que había estudiado, enseñado e incluso dirigido el colegio de San Ildefonso ${ }^{12}$.

Una de las principales demandas de los círculos radicales era la extinción de las comunidades religiosas que, contraviniendo las normas vigentes, aún existían. Desde la lógica del liberalismo, las congregaciones coartaban la libertad y la voluntad del individuo y entorpecían al desarrollo de una economía moderna. Así, desde los años de la Guerra de Reforma se habían dictado algunas disposiciones con el objeto de suprimirlas. En la «Ley de nacionalización de los bienes eclesiásticos» del 12 de julio de 1859, Benito Juárez ordenó la extinción de todas las órdenes masculinas y cuatro años después, en pleno enfrentamiento con las tropas francesas, hizo lo propio con las femeninas. Sin embargo, las consecuencias para hombres y mujeres fueron muy distintas. Mientras aquéllos podían permanecer como seculares, estas debían reincorporarse a la vida civil en una sociedad que les brindaba escasas posibilidades de inserción ${ }^{13}$.

Entre las órdenes, la Compañía de Jesús era históricamente la más cuestionada, pues, además de los puntos señalados, se le vinculaba con el monopolio educativo de las élites y con la obediencia absoluta de sus miembros a las directrices de sus superiores en detrimento de la soberanía nacional. Tras la expulsión decretada por Carlos III en 1767, estos religiosos regresaron por un breve periodo entre 1815 y 1820, cuando por resolución de las Cortes se vieron obligados a abandonar nuevamente las posesiones españolas. A México retornaron tres décadas más tarde. En septiembre de 1853, Antonio López de Santa Anna consintió la apertura de congregaciones, colegios, hospitales y noviciados y dispuso que les devolvieran sus antiguas propiedades, salvo el Colegio de San Ildefonso y aquellas que estuvieran dedicadas al servicio

dente constitucional de los Estados Unidos Mexicanos, a sus conciudadanos», El Siglo Diez y Nueve (México, 29 de julio de 1872): 2.

12 Para una revisión general de la administración de Sebastián Lerdo de Tejada véase, Cosío Villegas, 1973. Katz, 2000, vol. 9. Lira y Staples, 2010. Pi-Suñer, 2008.

13 Ley de nacionalización de los bienes eclesiásticos, 12 de julio de 1859, Dublán y Lozano, 1877, t. 8: 680-683; «Decreto del gobierno. Se extinguen en toda la Republica las comunidades religiosas» (26 de febrero de 1863), Dublán y Lozano, 1878, t. 9: 594-595; Decreto del gobierno. Declaraciones relativas a las personas e intereses de las religiosas exclaustradas, 13 de marzo de 1863, Dublán y Lozano, 1878, t. 9: 598-601. 
militar. Para evitar futuros conflictos, detalló que sus miembros serían considerados como mexicanos mientras estuvieran en el país, «sin poder alegar derecho alguno de extranjería» ${ }^{14}$. Sin embargo, el permiso tuvo una vida muy breve, pues en 1856 fue derogado por los diputados que, en aquel momento, además de elaborar una nueva Carta Magna, estaban revisando las disposiciones dictadas por el caudillo veracruzano en su última gestión ${ }^{15}$.

En esa coyuntura, el regreso de algunos jesuitas, que se registró al término de la Guerra de Reforma y, particularmente, después de la Intervención Francesa, se vislumbró como una consigna del Papa para violentar la Constitución y las leyes liberales. En 1868, tras varias denuncias en su contra, Benito Juárez ordenó una investigación a fondo. El 30 de abril, la policía descubrió a diversos miembros de la Compañía de Jesús in fraganti delito en el noviciado ubicado en la calle de San Lorenzo ${ }^{16}$. Tras su clausura, este se trasladó a San Javier Tepozotlán, donde siguió funcionando quince años más ${ }^{17}$.

En cuanto Lerdo de Tejada asumió la presidencia, la campaña se intensificó. Con el apoyo de otros periódicos, como San Baltasar del Distrito Federal y La Concordia de Veracruz, los redactores y colaboradores de El Monitor Republicano emprendieron una intensa campaña en contra de los miembros de la Compañía de Jesús que, desde su punto de vista, violentaba, como ninguna otra orden monástica, las Leyes de Reforma ${ }^{18}$. Entre los promotores

14 Decreto del gobierno. Se restablece la Compañia de Jesús, 19 de septiembre de 1853, Dublán y Lozano, 1877, t. 6: 671-672.

15 Decreto del Congreso Constituyente.- Se declara insubsistente el de 19 de septiembre de 1853, sobre jesuitas, 7 de junio de 1857, Dublán y Lozano, 1877, t. 8: 190-191. El asunto dividió a los constituyentes. Los promotores de la anulación del mandato señalaron que en el país existían suficientes órdenes religiosas para satisfacer la demanda de la población y que el retorno de los jesuitas contribuiría a «desviar más y más a la sociedad de su verdadero camino». Aquellos que se oponían argumentaron que los jesuitas educaban a los niños con «esmero, empeño y cariño», que podían prestar sus servicios en los estados invadidos por «tribus bárbaras»y, aún más importante, que la nación no sería «verdaderamente liberal» si, por temor, atentaba en contra de unos cuantos religiosos que estaban bajo disposición de las leyes (Dictamen de la mayoría de la Comisión de Negocios Eclesiásticos, presentado en la sesión del 6 de junio de 1856 y Voto particular de Manuel Buenrostro presentado en la sesión del 6 de junio de 1856, Zarco, 1857, t. 1: 379-383 y 383-388).

16 «Jesuitas», El Monitor Republicano, México, 2 de mayo de 1868: 3.

17 Staples, 1989: 24.

18 Juvenal, por ejemplo, denunció que salían a las calles con ropaje religioso, disfrazados y con máscaras como «en carnaval constante». Reconocía que el problema principal no era el atuendo que llevaban, sino la flagrante violación del Estado de derecho. Juvenal, «Boletín del Monitor», El Monitor Republicano (México, 20 de febrero de 1873): 1 y (México, 21 de febrero de 1873): 1 . 
destacaban el propio editor del diario liberal, Vicente García Torres bajo el pseudónimo de Tancredo, Enrique Chavarri — conocido como Juvenal-, Julio Vargas que firmaba como Pero Grullo y Juan A. Mateos, a la sazón secretario de la Suprema Corte de Justicia de la Nación.

\section{DESDE LA PRENSA SE INICIA LA CRUZADA}

En la primavera de 1873 , la noticia de que cuatro religiosos de la orden de San Ignacio de Loyola estaban por llegar a las costas del país dio un nuevo rumbo a la cruzada en contra de los jesuitas. En el verano, se llevarían a cabo elecciones para renovar el poder Legislativo y el tema ayudó a definir lealtades y enfrentamientos entre los círculos políticos en pugna ${ }^{19}$.

Desde las páginas de El Monitor Republicano, Juan A. Mateos se pronunció por expulsarlos del país. La Constitución — sentenció- autorizaba al Ejecutivo de la Unión para llevar a esos «revoltosos» a las puertas de la nación y devolverlos a las tierras europeas de donde habían partido o a cualquier otro sitio porque en México «la tolerancia no alcanza a cubrir la conspiración» ${ }^{20}$. En términos generales, la campaña se orquestó en torno a dos ejes. En primer lugar, los periodistas se esforzaron por demostrar que los jesuitas no eran «verdaderos católicos». El catolicismo «explicaron» es «una religión de paz, de consuelo, de humildad, de pobreza», que «tiene la igualdad por base y la caridad por fin»y cuyas armas eran tan solo «la predicación y el buen ejemplo». El jesuitismo, en cambio, bajo el pretexto de defender la religión, buscaba el poder y la riqueza sin reparar en los medios para alcanzar sus fines: «se apoderan de los gobiernos por la intriga, de los reyes por el confesionario, de las almas timoratas por el terror [...], de la juventud por la enseñanza». En segundo lugar, con ciertos tintes nacionalistas, contrapusieron al noble y sacrificado clero mexicano con el ambicioso jesuita extranjero. Mientras los sacerdotes nacionales marchaban al «desierto y a los pueblos tristísimos de la sierra», los foráneos disfrutaban en las grandes ciudades de «los goces del cibarita ( $\mathrm{sic}$ )». Mientras los primeros recibían en el confesionario solamente a los pobres, los segundos aconsejaban a los aristócratas que los colmaban

19 Para un análisis del papel de la prensa durante la República Restaurada en tanto vehículo de difusión de ideas y generadora de hechos políticos, véase Palti, LII / 4 (México D.F., abril-junio de 2003).

20 Mateos, Juan A, «Boletín del Monitor», El Monitor Republicano (México, 11 de marzo de 1873): 1; (12 de marzo de 1873): 1; (19 de marzo de 1873): 1; (25 de marzo de 1873): 1 (2 de abril de 1873): 1 . 
con obsequios. Mientras unos mendigaban por «un óbolo para decir misa» y no tenían vino para oficiar, los otros bebían en la mesa de los poderosos hasta enrojecer sus mejillas "con los vapores de la champagne» ${ }^{21}$.

Con el afán de poner en evidencia la perversidad de estos «apóstoles de la hipocresía», crearon una imagen demoníaca: hombres descoloridos o rubicundos, con la faz risueña, el cabello sobre la frente y los pies deformes, que tenían poderes fuera de lo común: si se ponía a un jesuita solo en un «pueblo poco ilustrado», se le daban las armas de la religión, se le subía a la tribuna y se le dejaba predicar sus «doctrinas subversivas», muy pronto se haría patente su venenosa influencia. Las madres de familia llevarían las ideas del sacerdote al hogar, los jóvenes inexpertos acabarían odiando las instituciones y los viejos se convertirían en apóstoles de la conspiración. Los compararon con víboras que viven bajo el amparo de la libertad para herirla de muerte, plagas que carcomen los cimientos de las instituciones, turbas de vampiros o tigres que se ocultan entre los zarzales para asechar mejor a los indefensos viajeros. Como prueba adicional apelaban a la larga historia de expulsiones y a las que en esos momentos estaban sufriendo en diversos países como Alemania, Francia y Guatemala 22 .

Sin tomar muy en serio el asunto, los sectores conservadores se burlaron, a través de las páginas de La Voz de México, su principal órgano de difusión, de que la llegada de cuatro jesuitas había puesto «en alarma [...] al avispero liberalesco», a tal grado que unos exclamaban que era necesario pedir armas a los Estados Unidos y otros proponían que se otorgara un premio al químico que descubriera una sustancia capaz de destruir su maléfica influencia ${ }^{23}$.

\section{LA CRUZADA LLEGA A LA TRIBUNA PARLAMENTARIA}

El 5 de abril de 1873, tres legisladores - Nicolás Lemus, Jesús Alfaro y Francisco Hernández y Hernández-, con el apoyo de las diputaciones de Coahuila y de Yucatán, presentaron ante el Congreso una propuesta para que el presidente de la República ordenara, en un plazo no mayor de veinte días, la expulsión del país de todas «las personas pertenecientes a la llamada "Com-

21 Además de los artículos citados, de Juan A. Mateos, véase Alcestes, «Los jesuitas», El Monitor Republicano (México, 3 de abril de 1873): 1-2; Pero Grullo, «Boletín del Monitor», El Monitor Republicano (México, 26 de marzo de 1873): 1; Tancredo, «Boletín del Monitor», El Monitor Republicano (México, 17 de abril de 1873): 1.

22 Idem.

23 «QQué valen los enemigos de la Iglesia?», La Voz de México (México, 1 de abril de 1873): 1-2 y (México, 2 de abril de 1873): 1. 
pañía de Jesús" [...] cualquiera que sea su denominación o carácter con que ejercen su ministerio». Fundamentaban la solicitud en el artículo 33 constitucional y en la ley del 7 de junio de 1856, aquella que derogaba el decreto mediante el cual tres años antes Antonio López de Santa Anna había restablecido dicha orden religiosa. Los legisladores dieron entrada a la iniciativa ${ }^{24}$. El Diario Oficial, que fungía como vocero del gobierno, advirtió que el Ejecutivo acataría la resolución del poder legislativo ${ }^{25}$. Días más tarde, el Congreso de Puebla ordenó la salida de los jesuitas del estado y se informó que en Oaxaca harían lo propio. En conjunto, las propuestas desataron un intenso debate en prensa ${ }^{26}$.

El Monitor Republicano secundó la moción. Esperaban que la iniciativa fuera aprobada por el Congreso «en beneficio de la sociedad y afianzamiento de la paz pública». Mientras tanto, siguieron describiendo los mecanismos a través de los cuales contravenían las leyes y pugnando por su expulsión. Se declaraban partidarios decididos de la tolerancia religiosa, pero que no lo podían ser cuando, en nombre de esa garantía, se trataba de minar el sistema político adoptado. Tancredo sostuvo que la disposición era legal y conveniente porque estaba comprobado que tales individuos eran perniciosos y el país necesitaba librarse de ellos para poder consolidar sus instituciones ${ }^{27}$.

La mayor parte de la prensa, sin embargo, manifestó su desacuerdo. Los periódicos conservadores se opusieron al «tiránico proyecto». En las primeras editoriales publicadas en $L a$ Voz de México, los redactores advirtieron que la propuesta implicaba una «extralimitación» de las funciones del poder Legislativo porque este no podía ordenar al Ejecutivo en qué momento utilizar una de las facultades que la Constitución le confería. Consideraban que, de acuerdo con el artículo 33, correspondía al presidente calificar a los extranjeros perniciosos y dicha libertad se vería limitada si el Congreso le indicaba cuán-

24 Arteaga, José S., «Una proposición inadmisible», La Bandera de Juárez (México, 9 de abril de 1873): 1-2.

25 Citado por El Pájaro Verde (México, 28 de abril de 1873): 1-2.

26 «Los jesuitas», La Bandera de Juárez (México, 14 de abril de 1873): 1-2; «Atroz atentado», La Bandera de Juárez (México, 23 de abril de 1873): 2; «Expulsión de jesuitas», El Monitor Republicano (México, 22 de abril de 1873): 3; «Algo sobre jesuitas», El Siglo Diez y Nueve (México, 25 de abril de 1873): 3.

José Gutiérrez Casillas, en su libro Jesuitas en México durante el siglo XIX, sostiene que la difusión de la noticia de lo que estaba acaeciendo en Oaxaca fue parte de la campaña orquestada por El Monitor Republicano, México, pues en esa entidad no había religiosos de dicha congregación (Gutiérrez Casillas, 1972).

27 Tancredo, «El Boletín del Monitor», El Monitor Republicano (México, 8 de abril de 1873): 1-2; «Sobre expulsión de jesuitas», El Monitor Republicano (México, 10 de abril de 1873): 3 . 
do y a qué extranjeros debía expeler. Enfatizaron que la «invasión de facultades» resultaba especialmente grave cuando se atacaba el «principio fundamental» de la Constitución, esto es, el respeto a los derechos del hombre, tal como estaba consignado en el artículo $1 .^{\circ}$ Por otro lado, señalaron que la ley de 1856 ordenaba la disolución de la Compañía de Jesús, pero no la salida obligada de sus miembros. Mostraban confianza en que, independientemente de la decisión de los diputados, Sebastián Lerdo de Tejada no echaría mano de la herramienta aludida. De otro modo, además de degradar su investidura, comprometería su reputación personal ${ }^{28}$.

Pero también importantes diarios liberales criticaron el proyecto. La Bandera de Juárez, bajo la dirección del ministro de la Suprema Corte de Justicia José S. Arteaga, emprendió una intensa lucha en contra. En la primera editorial sobre el tema publicada el 9 de abril, el jurista señaló que no habían prestado demasiada atención al asunto cuando los anhelos venían de «periodistas apasionados» o de los llamados «escritores públicos», pero ahora, que se había convertido en una iniciativa de ley, resultaba preocupante. Consideraba que la proposición de los diputados era anticonstitucional, antiliberal, antipolítica y antirracional. En primer lugar, el artículo 33 no hablaba de jesuitas por lo que no era posible desterrar a quienes lo fueran solo por serlo. Con dicho término querían abarcar una «generalidad indefinida y enteramente arbitraria»: a los clérigos que se llaman paulinos, a las Hermanas de la Caridad y quizás incluso a las señoras de buena posición social que se dedican a obras de beneficencia, a los jóvenes que rezan, a los banqueros, comerciantes o funcionarios públicos que son devotos o a los profesores de instrucción que enseñan materias religiosas. ¿Quién haría la calificación? - preguntaba- «¿se entregaría toda la sociedad, el hogar, la conciencia, a las pesquisas de la policía buscando jesuitas bajo «cualquier denominación»?». En segundo lugar, la propuesta implicaba usurpación de funciones porque el Congreso no podía recomendarle al Ejecutivo a quién debía expulsar, como no podía decirle a ningún juez qué sentencia dictar. Según Arteaga, la ley del 6 de julio de 1856 tampoco sustentaba la propuesta de los diputados. Por otro lado, la iniciativa atacaba de «la manera más ruda» algunas libertades individuales como la de pensamiento y la de tránsito. Por último, le preocupaba que reavivara la cuestión religiosa - ya casi aniquilada - y que renacieran las disensiones intestinas. De manera insistente, recalcó que no se trataba de una de-

28 «Un proyecto tiránico», La Voz de México (México, 8 de abril de 1873): 1, «Los jesuitas», La Voz de México (México, 15 de abril de 1873): 1; «Un proyecto tiránico», La Voz de México (México, 17 de abril de 1873): 1-2. 
fensa de los clérigos, sino de la Constitución, de los principios liberales y de la razón ${ }^{29}$.

En otro artículo publicado a finales del mes José S. Arteaga reiteró que expulsar «a ojo de buen cubero a cuantos bajo cualquier denominación se les tenga por jesuitas» era una «violación expresa y escandalosa de todas las garantías constitucionales» que resultaba más peligrosa que «todos los retrógrados juntos», incluidos los miembros de la Compañía de Jesús. De esa forma se reducía toda la política a una simple premisa: «o profesas mis ideas o te aniquilo» y qué diferencia había - cuestionaba - entre semejante principio y los de la Inquisición ${ }^{30}$.

La postura de El Siglo Diez y Nueve se mantuvo, a grandes rasgos, en esta misma línea. Su editor, José María Vigil, advirtió que estaba consciente de «las tendencias antiliberales de esos activos misioneros de la teocracia», pero que la persecución no era el medio más eficaz para combatirlas. Por otro lado, aseguró que legalmente no había sustento para expulsar a todos los jesuitas. Cuestionaba qué se haría con los nacidos en territorio nacional: «¿se les considera por ventura extranjeros?» ${ }^{31}$.

\section{LAS PRIMERAS ACCIONES}

A finales de abril, el Congreso determinó que, por la gravedad del asunto y la alarma que había producido en la opinión pública, era preciso estudiarlo detenidamente. Solicitaron a los gobernadores de las entidades federativas información sobre el tema. Específicamente formularon cuatro preguntas:

1. Si existen datos en el gobierno de que hayan venido jesuitas al país y cuál era su procedencia.

2. Si los que hay viven en comunidad y cuáles son los lugares de residencia.

3. Si colectiva o individualmente hacen propaganda en contra de las instituciones de la República y los medios de que se valen para esto.

4. Si antes existían en el país bajo alguna otra denominación distinta de la de «Compañía de Jesús» ${ }^{32}$.

29 Arteaga, José S., «Una proposición inadmisible», La Bandera de Juárez (México, 9 de abril de 1873): 1-2.

30 Arteaga, José S., «Sobre el mismo tema», La Bandera de Juárez (México, 30 de abril de 1873): 1-2.

31 Vigil, J. M., «Los Jesuitas», El Siglo Diez y Nueve (México, 17 de abril de 1873): 1.

32 Expediente relativo a la expulsión de un grupo de jesuitas en 1873, Archivo Histórico del Distrito Federal (AHDF), México, D.F., Fondo del Gobierno del Distrito Federal, Sección Negocios del Interior, caja 9, foja 5. 
Poco a poco irían llegando las respuestas. Las autoridades de Huajuapam, en el estado de Oaxaca, por ejemplo, denunciaron la presencia de unos religiosos en la región. El gobernador de la entidad ordenó que se investigara y que, en caso de ser cierto, se aprehendiera a los implicados y se les consignara ante la instancia judicial competente. Sin embargo, no fue necesario porque, en cuanto los sacerdotes se enteraron, «dejaron aquellos rumbos espontáneamente» ${ }^{33}$.

En la Ciudad de México, las investigaciones efectuadas por las autoridades no dieron muchos resultados. El 7 de mayo se informó que se habían practicado visitas a los puntos indicados, pero que no se habían encontrado jesuitas viviendo en comunidad, tan solo unos cuantos colegios. Se mencionaba, específicamente el Convento de San Diego en Tacubaya en donde algunos religiosos de la orden de los Paulinos vivían de la caridad pública y de lo que el culto originaba en aquella iglesia ${ }^{34}$. Sin embargo, el 20 de mayo El Siglo Diez y Nueve publicó, bajo el apelativo de «Colaboración», un artículo enviado por José M. Pérez en el que se denunciaba la existencia de congregaciones religiosas que contravenían las leyes en la materia. Retomando el espíritu «nacionalista» al que hemos hecho referencia, el autor advirtió que la mayoría de los infractores eran de origen extranjero y, de manera particular, se refirió a los jesuitas. Los ataques no eran nuevos, lo interesante es que presentaba una lista de lugares en los que hombres y mujeres seguían viviendo en comunidad y, en algunos casos, haciendo propaganda en contra del gobierno y de las instituciones republicanas. En San Cosme, por ejemplo, había un miembro de la orden de San Ignacio de Loyola que aconsejaba a los feligreses rebelarse para defender a la Iglesia, «a imitación de José de Arimatea y Nicodemus, que trataron de sublevar al pueblo de Jerusalem para liberar a Jesús de la sentencia de Pilatos» ${ }^{35}$. En una pequeña nota, los editores del diario puntualizaron que si bien confiaban en que José M. Pérez era una persona bien informada, no podrían responder por la exactitud de las noticias y que tocaba a las autoridades hacer la averiguación correspondiente. No estaban conformes con la propuesta de expulsarlos del país, pero tampoco creían conveniente tolerar que violaran las disposiciones vigentes ${ }^{36}$.

Esa misma noche, la policía capitalina se presentó en algunas casas en donde había reunión de religiosas, las puso en la calle y las instó a no volver

33 «Así se hace», La Bandera de Juárez (México, 28 de mayo de 1873): 2.

34 Expediente relativo a la expulsión de un grupo de jesuitas en 1873, loc. cit., foja 6.

35 Pérez, José M., «Los jesuitas, las comunidades religiosas mexicanas y las leyes de reforma (colaboración)», El Siglo Diez y Nueve (México, 20 de mayo de 1873): 1-2.

36 «Los conventos», El Siglo Diez y Nueve (México, 20 de junio de 1873): 3. 
a congregarse ${ }^{37}$. Posteriormente acudieron al Seminario y apresaron a varios eclesiásticos - mexicanos y extranjeros - que «hacían vida conventual». De acuerdo con una crónica que se publicó días después en La Voz de México,

muy entrada la noche [...] un gefe militar cercó la manzana de San Camilo, cual si fuese para el asalto de una fortaleza. Penetró al apacible recinto del Colegio con cincuenta soldados, dejando guardias en el zaguán, apostando centinelas en varios puntos, y apoderándose de los profesores y alumnos de aquella casa, con la fiereza y el aparato del guerrero que sorprende a una guarnición descuidada en un campamento. Algunos policías le acompañaban. Separó a los alumnos y llamó por lista a los profesores. Presentáronse uno a uno, y no se ocultaron el Vice-Rector y el catedrático de Filosofía que yacían en cama por enfermedad peligrosa. A estos enfermos les pusieron guardias y centinelas de vista, como si fueran plagiarios o gefes de bandidos. Bien guarnecidos los cuartos de estos dos enfermos, el gefe militar reunió a los profesores aprehendidos, y a otras personas que no lo eran, y como prisioneros al cabo de una recia batalla, para que marchasen al palacio del gobernador, director inmediato de la inolvidable jornada ${ }^{38}$.

Al día siguiente, el Diario Oficial informó que más de 200 señoras fueran puestas en la calle y como 70 hombres, entre jesuitas, frailes y sirvientes, llevados a la Diputación. Se aclaraba que el operativo se había llevado a cabo de noche para que la acción de la policía fuera más eficaz y para no alarmar a los habitantes de la ciudad. Sin embargo, por especial recomendación del gobierno del Distrito, se había tratado a todos los afectados con «urbanidad» ${ }^{39}$.

Las aprehensiones continuaron a lo largo de los días subsecuentes. El 21 de mayo detuvieron al presbítero de origen español Eduardo Sánchez, mientras dictaba cátedra de religión en un colegio. Un miembro de la policía secreta le dijo que el gobernador del DF quería hablar con él y cuando llegaron a la diputación le informaron que estaba detenido. Lo condujeron a la fuerza a través de la alcaldía a la pieza en la que se encontraban los otros religiosos. Las declaraciones de los afectados corroboran las «brutales» condiciones en las que se efectuaron las detenciones. Al tiempo que las notas periodísticas contribuyeron a dramatizar el episodio que «al abrigo de la oscuridad de la

37 Algunas de las mujeres afectadas interpusieron un amparo ante el Juez Primero de Distrito. En dichos documentos se cuenta con extremo detalle lo acaecido esa noche (Expediente relativo a la expulsión de un grupo de jesuitas en 1873, loc. cit., fojas 84-89 y 102104).

38 «Violación de las garantías», La Voz de México (México, 10 de junio de 1873): 1-2. Véase también: «Un atentado», La Voz de México (México, 22 de mayo de 1873): 1.

En todas las citas, se respetará la ortografía de la fuente original.

39 «La aprehensión de los jesuitas y las monjas», citado por El Siglo Diez y Nueve (México, 22 de mayo de 1873): 3 . 
noche anterior había turbado el reposo de varios de sus moradores, que al amparo de las garantías individuales que la ley fundamental les proteje se habían entregado al descanso». Se hablaba de monjas que erraban de calle en calle y presos hacinados en la cárcel pública de la ciudad ${ }^{40}$.

La policía también dio cuenta del «reprochable» comportamiento de los religiosos. Informaron, por ejemplo, que el padre Morandi hizo tal escándalo que «algunos fanáticos intervinieron para evitar que se lo llevara la policía» y que el presbítero Coll estuvo a punto de provocar un motín, por lo que tuvieron que dejarlo incomunicado durante algunas horas. Además, amenazó que el gobierno mexicano debía esperar «las consecuencias del de España» ${ }^{41}$.

Como evidencia del ambiente de crispación cabe mencionar algunas cartas. El mismo 23 de mayo un tal Alegría, en nombre de la «Sociedad Nacional Sebastián Lerdo de Tejada», felicitó a Tiburcio Montiel, Gobernador del Distrito Federal, por «la enérgica medida [...] en defensa de los principios liberales», que era una prueba más de que las leyes de Reforma no podían ser violadas «sin atraer sobre sus infractores la indignación del pueblo y la severa mano de la autoridad que sabe cumplir con los deberes que le impone la sagrada misión que tiene de velar por los intereses sociales y las instituciones que nos rigen ${ }^{42}$. Pero el funcionario también recibió algunos mensajes firmados con pseudónimos - como un católico - en los que se defendían a las ancianas y a los «venerables sacerdotes» cuyos únicos delitos eran ilustrar a la juventud con «las ideas santas de la moral cristiana» y no haber nacido en

40 J. A., «Acontecimiento alarmante», La Bandera de Juárez (México, 23 de mayo de 1873): 2-3; «Cuestión de actualidad (editorial)», La Bandera de Juárez (México, 28 de mayo de 1873): 1-2.

41 Expediente relativo a la expulsión de un grupo de jesuitas en 1873, loc. cit., foja 59. «Los jesuitas», El Siglo Diez y Nueve (México, 29 de mayo de 1873): 3.

En esta nota se informa que en el mismo domicilio se aprehendió al padre Artola, «presidente de la orden de los jesuitas». Sin embargo, de acuerdo con información de Gutiérrez Casillas este logró escapar de los guardias que lo esperaban mientras él escuchaba confesiones en el templo de Santo Domingo. Tomó un tren con destino a Orizaba y se ocultó en la hacienda de Tlalmanalco, Veracruz. Tiempo más tarde, le informaron que era preferible que saliera voluntariamente del país pues «ya pasaban de 14 veces que la policía lo había buscado en México y en Veracruz, y no pararía de seguro hasta encontrarlo siendo como era superior de todos los Jesuitas mexicanos y reconocido públicamente extranjero». Desde el barco que lo conduciría a los Estados Unidos, mandó un telegrama a los suyos en el que informaba que «varios jesuitas extranjeros se desterraban espontáneamente del país, esperando con ello hacer más benigna la sentencia de los presos» (Gutiérrez Casillas, 1972: 207). 132.

42 Expediente relativo a la expulsión de un grupo de jesuitas en 1873, loc. cit., foja 
México $^{43}$. Incluso le remitieron algunos anónimos en los que, «con palabras injuriosas», lo amenazaban de muerte ${ }^{44}$.

Dados los antecedentes, circularon rumores de que todos los detenidos iban a ser desterrados de forma inmediata. Así, algunos diputados - Francisco Gómez del Palacio, Juan José Baz, Pablo Herrera y Gabriel Islas - presentaron en la Cámara una propuesta para solicitar a la Secretaría de Gobernación informes al respecto. Concretamente les interesaba saber si el gobierno había ordenado la salida de los sacerdotes apresados en el Seminario y, en caso de ser cierto, si la disposición también comprendería a los mexicanos. Los diputados insistieron que no tenían «ánimo de poner inconvenientes al cumplimiento de toda ley, disponga lo que dispusiere, ni de interrumpir el uso de ninguna facultad que el gobierno tenga». Otra facción consideró que no era necesario ni conveniente solicitar dicha información ${ }^{45}$. Más allá de la discusión específica, cabe señalar que en esa ocasión los legisladores que tomaron la palabra no cuestionaron la prerrogativa del gobierno - en particular del Ejecutivo - de expulsar a los extranjeros que juzgara perniciosos. De hecho en una extensa nota publicada el día 23 en La Bandera de Juárez, José S. Arteaga lamentó que la reclamación «se redujera solo a los presos mexicanos asegurando que con respecto a los extranjeros podía el gobierno hacer lo que la gana le diera porque estos no gozaban de las garantías constitucionales» ${ }^{46}$.

Finalmente, Lerdo de Tejada, consciente de que no podía desterrar a los religiosos de origen mexicano, ordenó la salida solamente de los 17 extranjeros, quienes, de manera casi inmediata, interpusieron un amparo ${ }^{47}$. Sin embargo, de acuerdo con el testimonio de uno de los afectados, permanecieron en la cárcel de la Diputación durante cuatro días y de ahí los llevaron a la de Belén, donde — recalcó - «extinguen su condena los más insignes malhechores». Finalmente, el 28 los dejaron en libertad bajo caución, ofrecida por el Lic. Manuel Bustos, quien dio como fianza su hacienda del Sabino valuada en $\$ 50.000$ con la sola condición de que los presos se presentaran en la víspera del embarque. Los religiosos volvieron a sus labores ${ }^{48}$.

43 Septién, Alfonso, «Revista de los estados», La Voz de México (México, 5 de junio de 1873): 1-2.

44 «Anónimos», El Siglo Diez y Nueve (México, 27 de mayo de 1873): 3.

45 Diario de los Debates (México, sesión del día 21 de mayo de 1873): 566-571.

46 J. A., "Acontecimiento alarmante», La Bandera de Juárez (México, 23 de mayo de 1873): 2-3.

47 Expediente relativo a la expulsión de un grupo de jesuitas en 1873, loc. cit., fojas 35, 36, 44-45.

48 Alegato que en defensa del Presbitero D. Luis Mónaco, deportado por el Presidente de la República, hizo el Lic. D. Miguel Martínez para la Suprema Corte de Justicia, 19 de 
El 4 de junio, el juez José A. Bucheli dictaminó la suspensión del destierro mientras se resolvía el juicio de amparo. En términos generales, reconoció que, conforme al artículo 33 constitucional, correspondía al Ejecutivo expulsar a los extranjeros perniciosos. Pero advirtió que, en este caso en particular, debido a que la orden se había dictado porque los implicados habían cometido un delito sancionado por la ley, debía seguirse el procedimiento judicial tal como estaba estipulado en los artículos 20 y 21 de la Carta Magna ${ }^{49}$. La decisión del juez causó gran revuelo. Algunos aplaudieron la medida, pero otros alegaron que dados los «usos y costumbres» del magistrado, era obvio que había «falseado los principios del derecho constitucional» ${ }^{50}$.

Ante la confusión, la Secretaría de Gobernación se mantuvo firme, con el argumento de que la medida se había dictado con base en los términos del artículo 33 de la Carta Magna; y que el haber señalado la violación a las leyes de Reforma en la conducta de los clérigos, obedeció a la necesidad de explicar los motivos por los que fueron considerados perniciosos. En el comunicado respectivo, se puntualizó que el Ejecutivo podía ejercer dicha facultad de expulsar a un extranjero en la forma y modo que creyera más conveniente, sin necesidad de juicios previos que sirvieran de base para sus apreciaciones ${ }^{51}$.

Los redactores de El Monitor Republicano felicitaron al presidente «por la energía» con la que había actuado ${ }^{52}$. Pero la medida también ocasionó severas críticas. La Bandera de Juárez acusó al mandatario de pretender exacerbar los odios por cuestiones religiosas con el objeto de «congraciarse con los liberales» y advirtió que la medida de «tan extemporánea crueldad» causaría disgusto entre la mayor parte de la población ${ }^{53}$. José S. Arteaga denunció que al primer mandatario le gustaba todo lo «atentatorio y arbitrario», que actuaba como si quisiera «acostumbrar al pueblo al despotismo y a la tiranía» por si en los comicios que se avecinaban se consolidaba el «lerdismo». Tam-

julio de 1873. El documento se publicó en varias partes en La Voz de México en agosto y septiembre de 1873 . 164.

49 Expediente relativo a la expulsión de un grupo de jesuitas en 1873, loc. cit., fojas $162-$

50 Desde las páginas de El Monitor Republicano, por ejemplo, se encargaron de enfatizar que el juez no había fallado a favor de los jesuitas, que simplemente había ordenado se suspendiera la orden de expulsión en tanto se resolvía el caso. «Los jesuitas y el amparo», El Monitor Republicano (México, 11 de junio de 1873): 3.

51 «Gacetilla», La Voz de México (México, 29 de junio de 1873): 2-3.

52 «Expulsión de los jesuitas», El Monitor Republicano (México, 25 de mayo de 1873): 4.

53 «Expulsión de varios extranjeros», La Bandera de Juárez (México, 26 de mayo de 1873): 4 . 
bién criticaba a los conservadores y liberales exacerbados que, en conjunto, habían creado un clima de intolerancia y crispación política en el que, en la lucha contra el enemigo, todo era válido ${ }^{54}$. Se burlaban de aquellos que consideraban que Lerdo había actuado «queriendo ser fiel a la Constitución», en consonancia con su fe política y sus antecedentes liberales, porque estos estaban lejos de serlo. Antes de figurar al lado de Juárez - explicaban- era tenido como conservador moderado y después de que se unió al político oaxaqueño pasó por «liberal de circunstancia». Tampoco se le podía suponer un constitucionalista, pues la única norma que seguía era la de su conveniencia ${ }^{55}$.

Retomando el tema de las elecciones, José S. Arteaga habló de la existencia de dos partidos dentro de los círculos liberales: el de «la razón y de la legalidad» y el de «las pasiones y ligerezas». El primero - aseguró- tenía por enseñanza «el estricto cumplimiento de la Constitución y la práctica de los principios liberales», mientras que el segundo también apelaba a la Carta Magna, pero pretendía que los derechos que esta reconocía solo beneficiaran a los que pensaban como ellos. Consideraba que los últimos eran los enemigos más peligrosos. Hacía, por tanto, un amplio llamado a participar en los $\operatorname{comicios}^{56}$.

Los grupos católicos comenzaron a movilizarse. En los últimos días de mayo, un grupo de «distinguidas señoras y señoritas» se reunió con el presidente en el Palacio Nacional para abogar por las víctimas. De acuerdo con la versión difundida por $\mathrm{La}$ Voz de México, Lerdo les explicó que los sacerdotes debían salir de la república porque «habían faltado a las leyes y eran perniciosos». Ante el cuestionamiento de una de las mujeres, especificó que habían quebrantado las disposiciones que prohibían las comunidades y como muestra se refirió al templo de San Camilo. Otra de las presentes puntualizó que se trataba de un colegio que existía desde hacía mucho tiempo y que incluso estaba reconocido por el gobierno. Ante la pregunta de por qué habían apresado a otros religiosos que no vivían en comunidad, el Ejecutivo titubeante respondió que se reunían en las mañanas a rezar y estas, indignadas, advirtieron que si ello constituía un delito, debía castigarse a la sociedad en su conjunto porque las familias mexicanas también acostumbraban juntarse para orar. En seguida, manifestaron inconformidad por la forma en que procedieron las autoridades. Firme, el Ejecutivo aseguró que no se había cometido ningún $1-2$

54 J.A., «Cuestión de actualidad», La Bandera de Juárez (México, 28 de mayo de 1873):

55 «Fe política», La Bandera de Juárez (México, 28 de mayo de 1873): 2.

56 J.A., «Los dos partidos», La Bandera de Juárez (México, 2 de junio de 1873): 1-2. 
atentado, pues ni su origen ni su educación o antecedentes lo podían conducir a tales extremos. A lo que otra dama señaló que «esas mismas cualidades [...] fueron para una porción de la sociedad el augurio feliz de un acertado gobierno; pero con la pluma que se ha firmado el decreto de expulsión, se han borrado muchas simpatías; la opinión, señor presidente, clama, y muy alto, en contra de las determinaciones que se han llevado a cabo». Poco antes de que terminara la entrevista una señora suplicó que se hiciera justicia. De inmediato una de sus compañeras corrigió: «no, señor presidente, no suplicamos, pedimos justicia» ${ }^{57}$. También se reunieron con el ministro de los Estados Unidos con la esperanza de que este pudiera influir en la decisión del presidente ${ }^{58}$.

Por esas mismas fechas, más de treinta vecinos del distrito de Cuautitlán solicitaron al Presidente la revocación del acuerdo. En la carta, también publicada en el diario católico, aseguraron que en sus sermones «hablaban particularmente de los padres Pasionistas» nunca habían vertido «una sola palabra que aje la dignidad y derechos del Superior Gobierno, ni de ninguna de las autoridades constituidas». Se habían empeñado en moralizar a los pobladores de la región, «enseñándonos lo que debemos a Dios y a las autoridades que nos rigen; lo que nos debemos a nosotros mismos y a nuestros semejantes». Y a ellos — puntualizaron - les debían «el arreglo de muchos matrimonios extraviados» y la rehabilitación de «hombres que antes eran perpetrados del mal y de todo género de vicio» y que ahora estaban «reducidos al orden y entregados a su trabajo honesto como buenos ciudadanos» $»^{59}$.

Los sucesos de la capital alertaron a los religiosos que residían en otras regiones, dándoles tiempo para regularizar cualquier situación que pudiera provocar su expulsión. En Puebla, por ejemplo, salieron de la ciudad, se dispersaron en casas particulares y dejaron al frente del Colegio al presbítero Fructuoso Pontón y a un jesuita mexicano. Así, cuando el 27 de mayo se presentó el Jefe de la Policía, el director introdujo amablemente a los profesores como domiciliados en la ciudad. El funcionario informó al gobernador del estado que se había disuelto «la reunión de jesuitas que le había sido denunciada». El colegio seguiría funcionando. De todos modos, el gobierno

57 «La diputación de señoras», La Voz de México de 1873 (México, 31 de mayo de 1873): 1 .

58 El escritor criticó la actitud de las señoras. Cualquiera diría — señaló- que «hay en esto la intención de poner frente a un poder otro poder; de amenazar, si se quiere, al Presidente con la cólera de la nación americana». Juvenal, «Boletín del Monitor», El Monitor Republicano (México, 30 de mayo de 1872): 1.

59 «Remitidos», La Voz de México, México, 3 de junio de 1873: 2-3. 
no actuó con el mismo rigor en el resto del país. Al parecer, nadie se acordó de que en Tepozotlán estaba José Alzola ni que los padres Danadoni y Espinosa se encontraban en la región de Orizaba ${ }^{60}$.

\section{El ARTí́culo 33 EN EL CENTRO DEL DEBATE}

La medida dividió a los que hasta ese momento habían formado un frente común en contra de la posibilidad de que fueran expulsados todos los jesuitas del país. Algunos liberales, como José María Vigil, la secundaron. Otros, como José S. Arteaga y un diputado del mismo apellido - Eduardo F. Arteaga - reconocieron que el presidente había actuado conforme a derecho, pero de manera injusta y poco atinada porque la medida podía «recrudecer antiguas y amargas disensiones religiosas, atizar de nuevo el fuego de la guerra civil y todo en busca de un provecho personal». Por ello, consideraban urgente reformar el código fundamental ${ }^{61}$.

Desde la tribuna parlamentaria, el legislador encabezó una batalla contra del artículo 33. El 26 de mayo, propuso «borrar» del texto constitucional la facultad de expulsión, a la que que calificaba como un «contraprincipio tan deplorable como monstruoso», pues dejaba a los extranjeros «a merced del gobierno que, sin atender a ninguna de las garantías que se reconoce a todo hombre, puede expulsarlos del territorio nacional, si los juzga perniciosos» ${ }^{62}$. «Con una plumada» - agregaba el legislador - se destruía para los extranjeros «el principio fundamental de nuestra Constitución» ${ }^{63}$. Días más tarde, el propio Arteaga informó que en el Congreso, «apoderados los lerdistas de la mesa», no habían permitido siquiera que se le diera primera lectura a la iniciativa $^{64}$.

El desacuerdo generó un intercambio de opiniones, a través de la prensa, entre Eduardo F. Arteaga y José María Vigil. El primero sostuvo que el «alma» de la Carta Magna estaba en el artículo 1. ${ }^{\circ}$ Por tanto, resultaba absur-

60 Gutiérrez Casillas, 1972: 208.

61 «Expulsión de varios extranjeros», La Bandera de Juárez (México, 26 de mayo de 1873): 4.

62 En una pequeña nota aparecida el 5 de junio en La Bandera de Juárez, se alertaba que en cualquier momento el presidente Lerdo podría emplear el artículo 33 en contra de periodistas extranjeros. Por ello - insistían - era tan importante que se aprobara la iniciativa del diputado Arteaga. «Alerta», La Bandera de Juárez (México, 5 de junio de 1873): 3.

63 «Reforma constitucional», La Bandera Juarista (México, 2 de junio de 1873): 2.

64 Arteaga, Eduardo F., «La Voz de México», La Bandera de Juárez (México, 5 de junio de 1873): 1-2. 
do decir en el 33 que los extranjeros - «cuya calidad de hombres nadie puede negar»- no tenían garantías cuando el gobierno decidía expulsarlos. ¿Cómo al tratarse de los hombres - preguntaba - podían hacer distinciones entre mexicanos y extranjeros? Vigil, en cambio, no encontraba contradicción entre ambos preceptos constitucionales: uno sentaba las bases generales, el segundo, establecía una excepción. Por otro lado, advirtió que a pesar de los «inmensos progresos que ha hecho la civilización moderna», no era posible aún «borrar la distinción de nacionalidades», que existía incluso en Estados Unidos, «pueblo cosmopolita por excelencia», en donde se excluía a los foráneos de ciertos derechos ${ }^{65}$.

Otro de los redactores de El Siglo Diez y Nueve, Emilio Velasco, importante abogado que en las elecciones efectuadas ese mes obtuvo un escaño en el Congreso de la Unión, también utilizó sus páginas para apoyar la decisión del presidente. La expulsión de los jesuitas —intentaba demostrar - era conveniente, necesaria y legal. La argumentación era sencilla. Los religiosos, al vivir en comunidad, estaban violentando las Leyes de Reforma y dicha actitud era una declaración de guerra. Explicó que, tras la caída del Imperio, el clero mexicano había optado por «medios pacíficos» para hacer propaganda de sus ideas - y para combatir las de los otros credos - pero «los sacerdotes venidos del extranjero lo procuraban por la abierta desobediencia y por la excitación de las pasiones». Ajenos a la patria y destituidos de todo amor por ella, no les importaba que «nuevas perturbaciones» vinieran a asolarla, si ellas podían producirles mayor influencia y la satisfacción de sus ambiciones. Agregaba, además, que bastantes eran los males que sufría el país con los elementos disolventes que en él han nacido, para que a ellos se sumaran los que vienen de otros sitios, individuos a los no estaban «obligados a admitir ni a tolerar». El pueblo había utilizado su derecho para repeler al ejército francés que pretendía mezclarse en sus asuntos; ahora el Ejecutivo hacía lo mismo al expulsar como perniciosos a los sacerdotes extranjeros. Se trataba de una «facultad política» encaminada a garantizar la independencia y, como tal, no debía pasar por los tribunales. El Ejecutivo era el único facultado para tomar dicha decisión, tenía absoluta libertad de acción y, si bien era conveniente que explicara los motivos «por razón de cortesía», no estaba obligado a hacerlo. Finalmente advertía que, las naciones fuertes, para las que las «intrigas de algunos sujetos» no representen un peligro, podían prescindir de este derecho, pero aquellas que, como México, «a menudo por razones de su de-

65 «El artículo 33 constitucional», El Siglo Diez y Nueve (México, 9 de junio de 1873): 2-3; «Sobre expulsión de los sacerdotes extranjeros», La Bandera de Juárez (México, 12 de junio de 1873): 2-3. 
bilidad se han visto envueltas en complicaciones por intrigas [...] no deben prescindir de ninguno de los derechos aceptados por el de gentes» ${ }^{66}$.

Como hemos mencionado, en un primer momento La Voz de México reconoció que el artículo 33 de la Constitución facultaba al presidente para expulsar a los extranjeros perniciosos. Sin embargo, tras la decisión de Lerdo de Tejada, la argumentación cambió radicalmente. A partir de ese momento, intentaron demostrar que no era una facultad del Presidente, sino del gobierno, esto es, los tres poderes actuando cada uno en «su respectiva órbita legal». Semejante distinción abría la posibilidad para que en el proceso interviniera el poder judicial, que fuera este el que decretara, después de un juicio y dando oportunidad para que el implicado se defendiera en una audiencia ${ }^{67}$.

\section{EN LOS TRIBUNALES}

Tras poco más de un mes y medio, el juez concedió el amparo a los quejosos. La sentencia resultó un tanto confusa. En primer lugar, reconoció que el presidente efectivamente estaba facultado para ordenar la expulsión de los extranjeros perniciosos y que, en condiciones normales, no era necesario que sometiera su decisión a los procedimientos establecidos en el artículo 20 de la Carta Magna. Pero este caso - explicó- era particular pues para decretar la salida de los susodichos había tomado en cuenta la ley del 12 de julio de 1859 y que, si lo había hecho para privarlos de su libertad y consignarlos ante las autoridades judiciales competentes, era justo que gozaran de las garantías que esta reconocía. Finalmente, señaló que los religiosos alegaban que la información rendida por las autoridades capitalinas era falsa y, ante la duda, debía resolverse del modo más benigno de acuerdo con los principios de equidad natural ${ }^{68}$.

El presidente remitió el asunto a la Suprema Corte de Justicia de la Nación. Durante la espera, continuó la guerra de declaraciones de uno y otro lado. José S. Arteaga intentó demostrar que a pesar de la redacción del artículo, sí procedía el amparo. Los redactores de El Monitor no se cansaron de publicar pequeñas notas exhortando a los ministros del máximo tribunal a negar el

66 Velasco, Emilio, «La expulsión de los jesuitas. Su conveniencia», El Siglo Diez y Nueve (México, 16 de junio de 1873): 1; «La expulsión de los jesuitas. Su necesidad» (México, 18 de junio de 1873): 1; «La expulsión de los jesuitas. Su legalidad» (México, 20 de junio de 1873): 1 .

67 «Cuestión constitucional», La Voz de México (México, 3 de junio de 1873): 1-2; «Expulsión de extranjeros», La Voz de México (México, 29 de junio de 1873): 1-2.

68 «El amparo de los jesuitas», El Monitor Republicano (México, 30 de julio de 1873): 3. 
amparo $^{69}$. El 10 de agosto, por ejemplo, publicaron una - con ciertas pretensiones líricas - dirigida a la «Señora Corte»,

Hablamos a la de Justicia, esperando que escuche nuestra voz; el gran partido liberal que se ha sacrificado porque las leyes de Reforma sean un hecho, la nación entera aguarda vuestro fallo sobre el amparo que a los jesuitas concedió la torpeza del juez Bucheli.

No vayáis a sancionar ese atentado contra nuestras instituciones.

Dejemos a un lado citas

De Livingston y la Sierra

¡Que se vayan los jesuitas

Con la música... a otra tierra! ${ }^{70}$

El 19 de agosto de 1873, en una sesión muy esperada, los ministros de la Suprema Corte de Justicia de la Nación revocaron la sentencia del 26 de julio y negaron el amparo a los quejosos. El argumento era sencillo: cuando en el artículo 33 se hablaba de «gobierno» se estaba haciendo referencia al poder Ejecutivo. Como evidencia, recordaron que dicha facultad se había utilizado en varias ocasiones por los presidentes en turno y nunca habían protestado los legisladores; además la Suprema Corte de Justicia había sancionado con diversas ejecutorias ese procedimiento. Y para rematar, señalaban que solo podía corresponderle al Ejecutivo «por tratarse de una facultad de seguridad pública y de alta policía».

La discusión debía ser secreta hasta que se publicara la sentencia (que solía hacerse con algunos días de retraso) pero, como parte de la lucha periodística que se había desatado desde meses atrás, de inmediato comenzó a filtrarse información. Al día siguiente, Juan A. Mateos publicó en El Monitor Republicano una crónica que reflejaba el entusiasmo con el que acogió el resultado. Le siguieron José S. Arteaga desde La Bandera de Juárez e Ignacio Manuel Altamirano a través de una carta dirigida al Procurador de la República y al ministro Arteaga que se publicó en El Siglo Diez y Nueve. También el Procurador General de la República, León Guzmán, dio a conocer su versión. Así, contamos con algunos testimonios que nos permiten reconstruir los argumentos esgrimidos por unos y por otros en aquella «solemne sesión» ${ }^{71}$.

69 «Los jesuitas», El Monitor Republicano (México, 1 de agosto de 1873): 3; «Los jesuitas», El Monitor Republicano (México, 12 de agosto de 1873): 4.

70 «Señora Corte», El Monitor Republicano (México, 10 de agosto de 1873): 3.

71 Mateos, Juan A. «El desamparo de los jesuitas», El Monitor Republicano (México, 20 de agosto de 1873): 1; Arteaga, José S., «La Suprema Corte», La Bandera de Juárez (México, 25 de agosto de 1873): 2-4; Altamirano, Ignacio M., «Al Sr. Procurador General de la Nación y al Sr. Magistrado Arteaga», El Siglo Diez y Nueve (México, 4 de septiembre de 1873): $1-2$. 
Aquella jornada, el primero en tomar la palabra fue el presidente del tribunal, José María Iglesias, que se pronunció por negar el amparo a los sacerdotes. Consideraba que el Ejecutivo había actuado conforme a las facultades que la Carta Magna le otorgaba ya que, si se dejaba en manos del poder judicial la resolución, había que esperar a que las acciones de los extranjeros se convirtieran en delitos, además de que se exigían trámites "siempre dilatados y estorbosos». Darle facultades a la Suprema Corte para corroborar que el expelido era extranjero y pernicioso equivaldría a usurpar la facultad del Ejecutivo. Agregó que tampoco era inconveniente que a los expulsados se les atribuyera previamente un delito porque el precepto constitucional era «absoluto y sin ninguna excepción». Iglesias sostuvo que «el artículo era conveniente y necesario tal como se encontraba para asegurar la paz pública y los intereses de la sociedad dejando espedita la acción del gobierno para arrancar del país que no le pertenecía al que veía le causaba daño sin podérselo probar en los tribunales». Por ello, no creía pertinente reformar dicho precepto constitucional.

En la misma línea fueron los discursos de Ignacio Ramírez e Ignacio Manuel Altamirano. El primero reconoció que nunca podría votar a favor de los jesuitas porque pertenecían al partido que siempre los había combatido y que «aun concediendo que debiera probarse para negarles el amparo que eran perniciosos, como a su juicio, no solo los mexicanos sino casi todas las naciones así los consideraban, [...] les negaría el amparo». Altamirano, tras calificar a los jesuitas como las personas «más perniciosas de la tierra» y de inconsecuentes a los que los defendían queriéndolos amparar cuando en otros momentos no habían alzado la voz en contra de la aplicación del artículo 33 constitucional, señaló que no había necesidad de reformarlo.

Las voces disidentes fueron de José S. Arteaga y León Guzmán. El redactor de La Bandera de Juárez, como en otras ocasiones, reconoció la facultad que el artículo 33 otorgaba al presidente, siempre y cuando los afectados fueran extranjeros y perniciosos. Si estos no lo eran, podían ampararse. Declaró que el «fanatismo político» podía ser aún más peligroso que el religioso, especialmente cuando los fanáticos estaban en el poder.

Al final, el Procurador de la República pronunció un extenso discurso en contra del artículo 33. De inicio, reconoció que el error más grande de su carrera política había sido, justamente, la aprobación de esta facultad como diputado en el Congreso Constituyente de 1856. Se lamentaba de haberle dado una «extensión tan grande» que lo hacía «verdaderamente alarmante, monstruoso y perjudicial» porque el Presidente podía expulsar «desde el primero hasta el último de los extranjeros, sin más que decir respecto a cada uno éste 
es pernicioso». Aceptaba que en determinadas circunstancias era imperioso expeler a algunos extranjeros, como los «agentes clandestinos de un gobierno extraño» que conspiraban contra la independencia, las instituciones o la paz pública. Pero, incluso en esas ocasiones, era necesario que se llevara a cabo una investigación previa para justificar la medida. Para los demás casos, estaba la policía para reprimir las faltas y los tribunales, para castigar los delitos. No concebía, por tanto, que se obligara a salir a un hombre que «no representa más que su propia individualidad». Ello era indigno y «altamente ofensivo a la justicia y al decoro nacional». Reconocía que, aunque en la orden decretada en contra de los jesuitas el presidente Lerdo había obrado conforme a derecho, había utilizado el artículo 33 como una herramienta política para levantar «su crédito que desfallecía». El acto podía ser injusto, pero era legal. Hacía, entonces, un llamado a la Suprema Corte para que esta, a su vez, sugiriera al Congreso una pronta reforma constitucional ${ }^{72}$.

De inmediato, El Monitor Republicano festejó el veredicto. «La República está de enhorabuena» por la salida de los religiosos y porque ha quedado «incólume una de las facultades más importantes que la Constitución asigna al poder ejecutivo» ${ }^{73}$. Al respecto, Juan A. Mateos apuntó:

El artículo 33 del pacto fundamental parece, a nuestro débil criterio, perfectamente pensado, y más nos afirmamos cuando se registra en las constituciones de los pueblos modernos más avanzados, y sea dicho para honor de México, que con alguna excepción, tributo forzoso al error de los hombres, se ha hecho buen uso de esa facultad, mereciendo no solo el asentimiento de la nación sino del extranjero ${ }^{74}$.

Desde las páginas de La Bandera de Juárez José S. Arteaga continuó la lucha. Eduardo F. Arteaga aseveró que la sentencia de la Suprema Corte no satisfacía «las exigencias de la justicia, ni las aspiraciones de la mayoría de los mexicanos, ni el bien del país». Ante todo «puntualizó» deben prevalecer las garantías, porque estas eran la base y el objeto de las instituciones, de las leyes y de los actos de autoridad. Pero en este caso, como había predominado la conveniencia política sobre la verdad, no se amparaba a los quejosos ${ }^{75}$. En

72 Para el fallo y el discurso del Procurador General, véase El Monitor Republicano (México, 23 de agosto de 1873): 1 y (México, 3 de septiembre de 1873): 3.

73 Juvenal, «Boletín del Monitor», El Monitor Republicano (México, 21 de agosto de 1873): 1 .

74 Mateos, Juan A., «El señor Procurador General», El Monitor Republicano (México, 23 de agosto de 1873): 1.

75 Arteaga, Eduardo F., «Editorial», La Bandera de Juárez (México, 25 de agosto de 1873): 1-2; «La sentencia de la Corte contra los sacerdotes extranjeros», La Bandera de Juárez (México, 1 de septiembre de 1873): 1-2. 
la editorial del 21 de agosto, A. Gómez lamentaba el resultado que «interesaba, más que a los diez y siete individuos que han hecho el papel de víctimas, a las instituciones y al porvenir de la República». Por otro lado, advertía que la sentencia frenaría la inmigración, pues los extranjeros ya no tendrían duda de que «están a merced del Presidente de la República, que a su apreciación, a su arbitrariedad, a su solo capricho o mala voluntad, puede arrancarlos de su comercio, de su domicilio, de su ministerio y de su hogar, sin recurso alguno que los salve» ${ }^{76}$.

A finales de septiembre, la Suprema Corte desechó por unanimidad la propuesta del Procurador General, León Guzmán ${ }^{77}$. Pero, para disgusto de sus detractores, los expulsados seguían en territorio nacional. En efecto, el asunto tomó más tiempo del acostumbrado. Por esas fechas se informó que se había ordenado la destitución de un empleado del máximo tribunal que había «retardado la devolución de los expedientes» al Juez Primero de Distrito ${ }^{78}$.

Para entonces, ya se habían efectuado las elecciones legislativas y el grupo cercano al presidente había alcanzado la mayoría ${ }^{79}$. Por esas fechas, tras varios meses de debates, el Congreso aprobó unas adiciones y reformas que buscaban «armonizar» las Leyes de Reforma con el texto constitucional ${ }^{80}$. Con ello se ratificaba la separación entre la Iglesia y el Estado y la educación laica en los planteles oficiales. El matrimonio quedaba confirmado como un contrato civil; los bienes raíces, fuera del alcance de las instituciones religiosas; y las órdenes monásticas proscritas. Dos días más tarde, se estipuló que todos los funcionarios y empleados del gobierno, para mantenerse en sus cargos, tenían que jurar la Carta Magna con las adiciones y reformas correspondientes ${ }^{81}$.

Desde las páginas de $L a$ Voz de México, se seguiría insistiendo en que la Constitución no representaba la voluntad del pueblo mexicano y no garantizaba los derechos a todos los hombres. En referencia a los extranjeros, adver-

76 Gómez, A., «Los sacerdotes expulsos», La Bandera de Juárez (México, 21 de agosto de 1873): 1 .

77 «Iniciativa», El Monitor Republicano (México, 21 de septiembre de 1873): 3.

78 Pero Grullo, «Ecos de Tacubaya», El Monitor Republicano (México, 21 de septiembre de 1873): 3; «El negocio de los jesuitas», El Monitor Republicano (México, 24 de septiembre de 1873): 3 .

79 Cosío Villegas, 1973: 98-99.

80 Congreso de la Unión. Declara algunas adiciones y reformas de la Constitución federal, 25 de septiembre de 1873 y octubre, Dublán y Lozano, 1882, t. 12: 502-504.

81 Decreto del Congreso. Sobre la protesta que deben prestar todos los funcionarios y empleados de la República de guardar y hacer guardar las adiciones y reformas declaradas el 25 del corriente, 27 de septiembre de 1873, Dublán y Lozano, 1882, t. 12: 504. 
tían, retomando el reciente caso de los jesuitas, que «los grandes goces y prerrogativas asegurados [...], cual si tuviesen todos una sola cabeza, [quedaban] guillotinados por mando de verdugo en el cadalso del art. 33, al antojo del gefe supremo de la República». Vaticinaban que los mexicanos podrían correr la misma suerte el día que el gobierno lo decidiera, pues «la misma inescrutable calificación que se dice puede hacer el Ejecutivo de los extranjeros como perniciosos, la puede hacer de los ciudadanos mexicanos, como extranjeros». Si para probar que individuos de otras nacionalidades eran perniciosos no se había escuchado a los afectados ni se había efectuado un juicio, lo mismo podría suceder para demostrar que un ciudadano era extranjero ${ }^{82}$.

Finalmente, el 15 de noviembre La Voz de México anunció que esa noche los sacerdotes viajarían por tren a Veracruz, llevándose «además del incalculable testimonio de su inocencia y de su virtud, el sentimiento que anima a la mayoría de los católicos mexicanos que deploran la injusticia de su expulsión; la gratitud de miles de nuestros compatriotas hacia los venerables hijos de Jesús». Confiaban en que en Texas serían recibidos «con el entusiasmo y el amor de México» y que ahí, «bajo las libres instituciones americanas», encontrarían «la tranquilidad, la seguridad y la paz que les ha negado el gobierno de un país católico» ${ }^{83}$. Efectivamente, al otro lado de la frontera, se reunieron los sacerdotes desterrados y, de acuerdo con Gutiérrez Casillas, al siguiente año se estableció un colegio. La comunidad llegó a albergar a 22 miembros, pero con el tiempo se disgregó. Algunos se fueron a Cincinnati o a Nueva York; otros viajaron a Europa; y unos más se quedaron en Texas con la esperanza de regresar a México ${ }^{84}$.

\section{CONSIDERACIONES FINALES}

En estas páginas, se analizó el impacto que tuvo, en medio de la contienda política, una campaña de prensa contraria a los miembros de la Compañía de Jesús. La facultad constitucional del titular del Ejecutivo para expulsar extranjeros perniciosos se convirtió en un asunto de interés nacional que impactó en los tres poderes del gobierno. El intenso debate sobre el artículo 33 contribuyó a fortalecerlo, pues obligó a los principales actores de la vida nacional a pronunciarse. Los conservadores no tenían duda, en aras de defender a los religiosos - mexicanos y extranjeros - se pronunciaron en contra

\footnotetext{
82 «iMentira!», La Voz de México (México, 15 de octubre de 1873): 1.

83 «Los PP Jesuitas», La Voz de México (México, 15 de noviembre de 1873): 3.

84 Gutiérrez Casillas, 1972: 212.
} 
de su aplicación; mientras que entre los liberales no hubo consenso. Algunos, como José María Iglesias, Ignacio Ramírez o Ignacio Manuel Altamirano, privilegiaron el cumplimiento de las Leyes de Reforma a la defensa de las garantías individuales. José S. Arteaga y León Guzmán, en cambio, rechazaron la decisión del presidente y demandaron, en repetidas ocasiones, la reforma del artículo correspondiente. Finalmente, el triunfo de los primeros dotó al artículo de legitimidad. A partir de entonces, si bien la salida de algunos extranjeros en particular podía desatar el debate, la demanda de reformar o suprimir el artículo 33 perdió fuerza. En 1886, incluso fue validado en la «Ley de extranjería y naturalización ${ }^{85}$. En palabras de Ignacio L. Vallarta, encargado de elaborar el proyecto respectivo, su derogación privaría al país de un medio que, en ciertas circunstancias, resultaba eficaz para defender su independencia ${ }^{86}$.

\section{REFERENCIAS CONSULTADAS}

PUBLICACIONES PERIÓDICAS

La Bandera de Juárez, México D.F.

El Monitor Republicano, México D.F.

El Pájaro Verde, México D.F.

El Siglo Diez y Nueve, México D.F.

La Voz de México, México D.F.

\section{BiBLIOGRAFÍA}

Aguilar Rivera, José Antonio, El manto liberal. Los poderes de emergencia en México, 1821-1876, México D.F., Instituto de Investigaciones Jurídicas - UNAM, 2001.

Ávila, Alfredo, «Liberalismos decimonónicos: de la historia de las ideas a la historia cultural e intelectual», Guillermo Palacios (coord.), Ensayos sobre la nueva his-

85 Ley de Extranjería y Naturalización, 20 de mayo de 1886, Dublán y Lozano, 1887, t. 17: 474-481.

86 Reconocía, sin embargo, que, para evitar abusos, era necesaria la aprobación de una ley orgánica en la que se definiera quiénes se considerarían extranjeros perniciosos y el procedimiento para hacerlo (Vallarta, 1886: 171). 
toria política de América Latina, siglo XIX, México D.F., El Colegio de México, 2007: 111-145.

Brading, David A., «Liberal Patriotism and the Mexican Reform», Journal of Latin American Studies, 20 / 1 (Cambridge, mayo de 1988): 27-48.

Cabrera Acevedo, Lucio, La Suprema Corte de Justicia en la República Restaurada, 1867-1876, México D.F., Suprema Corte de Justicia de la Nación, 1989.

Castillo Velasco, José María del, Apuntamientos para el estudio del derecho constitucional mexicano, México D.F., Imprenta del Gobierno, 1871.

Chenillo Alazraki, Paola, «Entre la igualdad y la seguridad. La expulsión de extranjeros en México a la luz del liberalismo decimonónico, 1821-1876». Tesis de Licenciatura en Historia, Facultad de Filosofía y Letras, Universidad Nacional Autónoma de México, 2009.

Cosío Villegas, Daniel, Historia moderna de México. La República Restaurada. La vida política, México D.F., Hermes, 1973.

Dublán, Manuel y José María Lozano, Legislación mexicana ó colección completa de las disposiciones legislativas expedidas desde la Independencia de la Repúbli$c a$, México D.F., Imprenta del Comercio, 1876-1886, tomos 1 a 17.

González, Luis, «El liberalismo triunfante», Historia General de México, México D.F., El Colegio de México, 1994, tomo 2: 897-1015.

Gutiérrez Casillas, José, Jesuitas en México durante el siglo XIX, México D.F., Porrúa, 1972.

Hale, Charles A., El liberalismo mexicano en la época de Mora (1821-1853), México D.F., Siglo Veintiuno Editores, 1995.

Hale, Charles A., «Los mitos políticos de la nación mexicana: el liberalismo y la Revolución», Historia Mexicana, XLVI / 4 (México D.F., abril-junio de 1997): 821-837.

Hale, Charles A., «Ideas políticas y sociales en América Latina, 1870-1930», Leslie Bethell (ed.), Historia de América Latina, Barcelona, Crítica, 2000, vol. 8: 1-64.

Hale, Charles A., La transformación del liberalismo en México a fines del siglo XIX, México D.F., Fondo de Cultura Económica, 2002.

Hamnett, Brian R., «Liberalism Divided: Regional Politics and the National Project during the Mexican Restored Republic, 1867-1876», The Hispanic American Historical Review, 76 / 4 (Durham, noviembre de 1996): 659-689.

Katz, Friedrich, «La Restauración de la República y el Porfiriato, 1867-1910», Leslie Bethell (ed.), Historia de América Latina, Barcelona, Crítica, 2000, vol. 9: 13-77.

Lira, Andrés y Anne Staples, «Del desastre a la reconstrucción republicana, 18481876», Erik Velásquez García, et al., Nueva Historia General de México, México D.F., El Colegio de México, 2010, pp. 443-486. 
Macedo, Pablo y Emilio Pardo, Compendio de los derechos y obligaciones del hombre y del ciudadano, México D.F., Imprenta de Flores y Monsalve, 1875.

Palti, Elías José, «La Sociedad Filarmónica del Pito. Ópera, prensa y política en la República Restaurada (México, 1867-1976)», Historia Mexicana 208, LII / 4 (México D.F., abril-junio de 2003): 821-837.

Perry, Laurens Ballard, «El modelo liberal y la política práctica en la República Restaurada, 1867-1876», Historia Mexicana, XXIII / 4 (México D.F., abril-junio de 1974): 646-699.

Pi-Suñer Llorens, Antonia, «Sebastián Lerdo de Tejada», Wil Fowler (coord.), Gobernantes Mexicanos, México D.F., Fondo de Cultura Económica, 2008, tomo 1: 337-360.

Staples, Anne, «El Estado y la Iglesia en la República restaurada», Anne Staples, et al., Los dominios de las minorías. República Restaurada y Porfiriato, México D.F., El Colegio de México, 1989: 15-53.

Vallarta, Ignacio L, Exposición de motivos del proyecto de Ley sobre extranjería y naturalización que por encargo de la Secretaría de Relaciones Exteriores ha hecho el Sr. Lic. D. Ignacio L. Vallarta, México D.F., Imprenta de Ignacio Cumplido, 1886.

Zarco, Francisco, Historia del Congreso Constituyente de 1856 y 1857. Estracto de todas sus sesiones y documentos parlamentarios de la época, México D.F., Imprenta de Ignacio Cumplido, 1857.

Zarco, Francisco, «Renovación y resistencia políticas», Óscar Flores Torres, Historiadores de México: siglo XIX, México D.F, Trillas, 2003: 346-348.

Fecha de recepción: 24 de mayo de 2011

Fecha de aceptación: 10 de febrero de 2012 


\section{Testing Liberalism. \\ The expulsion of «pernicious foreigners» in Mexico during the Restored Republic (1867-1876)}

In Mexico, during the Restored Republic (1867-1876), even though Liberalism became a fundamental element of national politics, the defense of legal equality would remain subjected to the strengthening of the State, and the party in power. This article analyzes the expulsion of 17 foreign Jesuits decreed in 1873 by President Sebastián Lerdo de Tejada. A close monitoring of the aftermath and the debate it generated provides evidence of the role this faculty had as a political tool in said process.

KEY woRDs: Liberalism; Restored Republic; Jesuits; foreigners. 